\title{
Availability and metabolism of purines of single-cell proteins in monogastric animals
}

\section{By D. Giesecke and W. Tiemeyer, Institute of Animal Physiology, University of München, West Germany}

Single-cell protein (SCP) consisting of the more or less processed cell mass of bacteria, yeasts, fungi or algae is considered to be a potential source of protein for the nutrition of animals and man. However, the high content of nucleic acids, which may attain $10-15 \%$ in fast-growing microbes, is one of the main factors limiting the use of SCP for human nutrition because of hyperuricemia (Anon. 1976). Processing of SCP in order to reduce the content of nucleic acids appears to result in loss of protein and reduction of the nutritive value (Kharatyan, 1978), increase of allergic factors (Scrimshaw \& Dillon, 1979) or increase of free bases (Tiemeyer et al. 1980).

Animal feeding and metabolism experiments are necessarily associated with the development of SCP products for evaluating inter alia the various criteria of protein quality, the utilization and/or uricogenic potency of nucleic acids and possible influences on animal productivity. In most of such experiments performed up to now the nucleic acid fraction of SCP has not been analyzed and important physiological characteristics of the experimental animals have frequently been ignored. This paper discusses some of the recent developments in the evaluation of nucleic acids in SCP.

\section{Nucleic acid analysis of SCP with reversed-phase HPLC}

The ion-exchange chromatography of purines and pyrimidines extracted from biological material has been improved by the use of high pressure liquid chromatography (HPLC) with cation-exchange columns (Clifford \& Story, 1976). The introduction of reversed-phase column materials into HPLC (Hartwick \& Brown, $\cdot 1976)$ enabled us to propose an even more efficient method for the analysis of nucleic acids in SCP (Giesecke et al. 1979). A detailed description of the extraction, enzymatic fractionation and isocratic separation of nucleosides and bases has been reported elsewhere (Tiemeyer et al. 198I). The principle steps are shown in Fig. I and chromatograms of nucleosides and bases of a bacterial RNA in Fig. 2. The method has also proved convenient for the determination of purine metabolites in $0.5 \mathrm{ml}$ blood plasma and in urine (Tiemeyer, Gaebler et al. 1982). Special methods were developed for allantoin (Tiemeyer \& Giesecke, 1982) and for metabolites of nucleic acids occurring in milk (Tiemeyer, Stohrer et al. 1982).

\section{Composition of nucleic acids in SCP}

The analysis of nucleic acids in SCP provides information on the purines and pyrimidines occurring as constituents of RNA, DNA and nucleosides or as free 


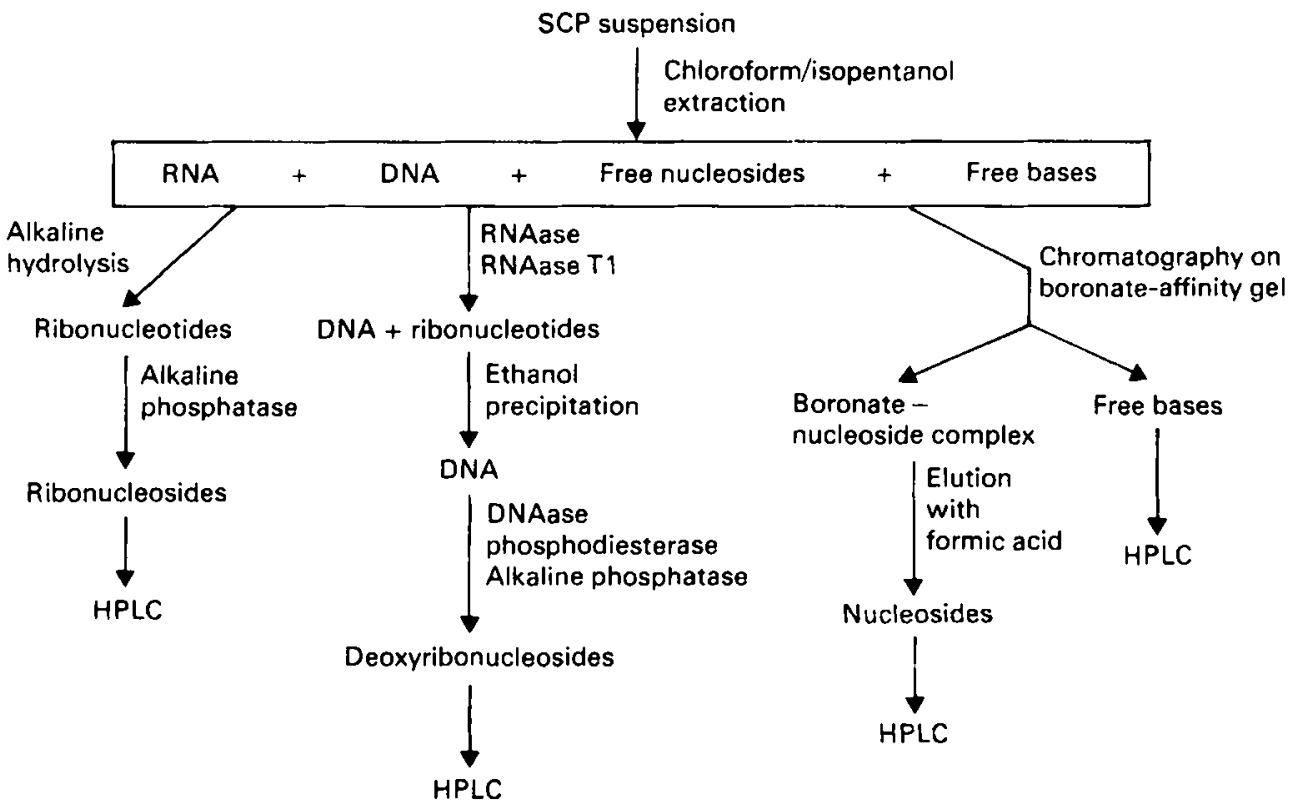

Fig. I. Principle steps of nucleic acid analysis of SCP.
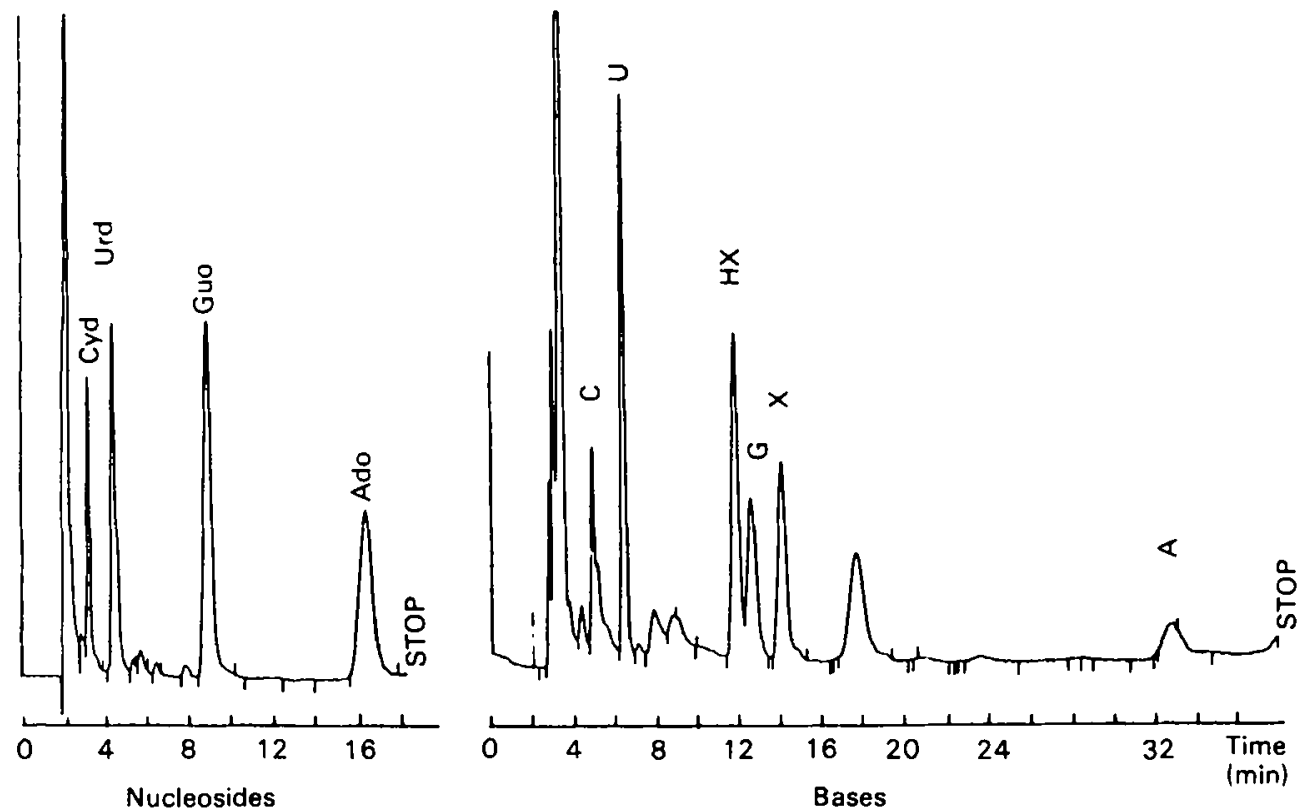

Fig. 2. HPLC chromatograms of RNA nucleosides and free bases of SCP (Methylomonas clara). A, adenine; Ado, adenosine; C, cytosin; Cyd, cytidine; G, guanine; Guo, guanosine; $\mathrm{HX}$, hypoxanthine; U, uracil; Urd, uridine; $\mathrm{X}$, xanthine. 
bases. Such information will not only indicate the potential availability of bases in the materials examined but is also necessary for an understanding of the digestion and absorption of the individual compounds. A selection of SCP products of bacteria, yeasts and fungi obtained from various sources and examined by the methods given above are listed in Tables $I$ and 2. More complete analytical results including amino acids have been reported elsewhere (Tiemeyer et al. 1981). The influences of the microbial species, of the energy substrates used and of the drying procedure on nucleic acid and base composition are obvious. As would be expected from the molecular structure of RNA the ratio of purines and pyrimidines is not necessarily unity as in DNA, although this has been presumed in many animal experiments. A comparison of the purines in selected foods is given by Clifford \& Story (1976). As has been shown eleswhere (Tiemeyer et al. 1980), a bacterial SCP, highly purified for food purposes, may still contain more than $r o \mathrm{~g}$ purines $/ \mathrm{kg}$.

\section{Physiological aspects of nucleic acid digestion in certain monogastric species}

If monogastric species are chosen for the evaluation of nucleic acid digestion and purine metabolism when SCP diets are fed, the microbial ecology of the gut, the activity of intestinal nucleolytic enzymes, and species differences in purine and pyrimidine absorption as well as differences in the metabolites excreted must be considered.

Apart from ruminants, considerable microbial activity has been confirmed in the stomach of the piglet and pig, in the forestomach of the rat and the mouse and in the crop of the chicken. Consequently, if SCP if fed to these species both the microbial breakdown of nucleic acids and bases from SCP and from the host animal has to be anticipated. Based on a study of ribonuclease concentration in the pancrease of vertebrates, Barnard (1969) put forward the hypothesis that the

\section{Table I. Products of single-cell protein analysed}

\begin{tabular}{|c|c|c|c|c|c|}
\hline Single-cell protein & & $\begin{array}{l}\text { Energy } \\
\text { ubstrate }\end{array}$ & $\begin{array}{l}\text { Drying } \\
\text { process }\end{array}$ & $\begin{array}{c}\mathrm{DM} \\
(\mathrm{g} / \mathrm{kg})\end{array}$ & $\begin{array}{c}\text { True } \\
\text { protein } \\
\text { (g/kg DM) }\end{array}$ \\
\hline $\begin{array}{l}\text { Bacteria } \\
\text { Methylomonas clara } \\
\text { Alcaligenes eutrophus I } \\
\text { Alcaligenes eutrophus II } \\
\text { Alcaligenes eutrophus III }\end{array}$ & $\begin{array}{l}\text { (I) } \\
(2) \\
(1) \\
(2)\end{array}$ & $\begin{array}{l}\text { Methanol } \\
\text { Fructose } \\
\text { Fructose } \\
\text { Fructose }\end{array}$ & $\begin{array}{l}\text { Spray } \\
\text { Freeze } \\
\text { Spray } \\
\text { Freeze }\end{array}$ & $\begin{array}{l}930 \\
896 \\
933 \\
909\end{array}$ & $\begin{array}{l}620 \\
695 \\
567 \\
688\end{array}$ \\
\hline $\begin{array}{l}\text { Yeasts } \\
\text { Candida boidinii } \\
\text { Saccharomyes cerevisiae }\end{array}$ & $\begin{array}{l}(3) \\
(4)\end{array}$ & $\begin{array}{l}\text { Methanol } \\
\text { Whey }\end{array}$ & $\begin{array}{l}\text { Freeze } \\
\text { Freeze }\end{array}$ & $\begin{array}{l}913 \\
916\end{array}$ & $\begin{array}{l}430 \\
380\end{array}$ \\
\hline $\begin{array}{l}\text { Fungi } \\
\text { Geotrichum candidum }\end{array}$ & (5) & $\begin{array}{l}\text { Sugar-beet } \\
\text { pulp }\end{array}$ & Freeze & 906 & 280 \\
\hline
\end{tabular}

-Supplied by (1) Hoechst, Frankfurt; (2) Institute of Microbiology, University Göttingen; (3) Nuclear Research Plant KFA, Jülich; (4) Federal Dairy Research Center, Kiel; (5) IPAT, Technical University, Berlin. 


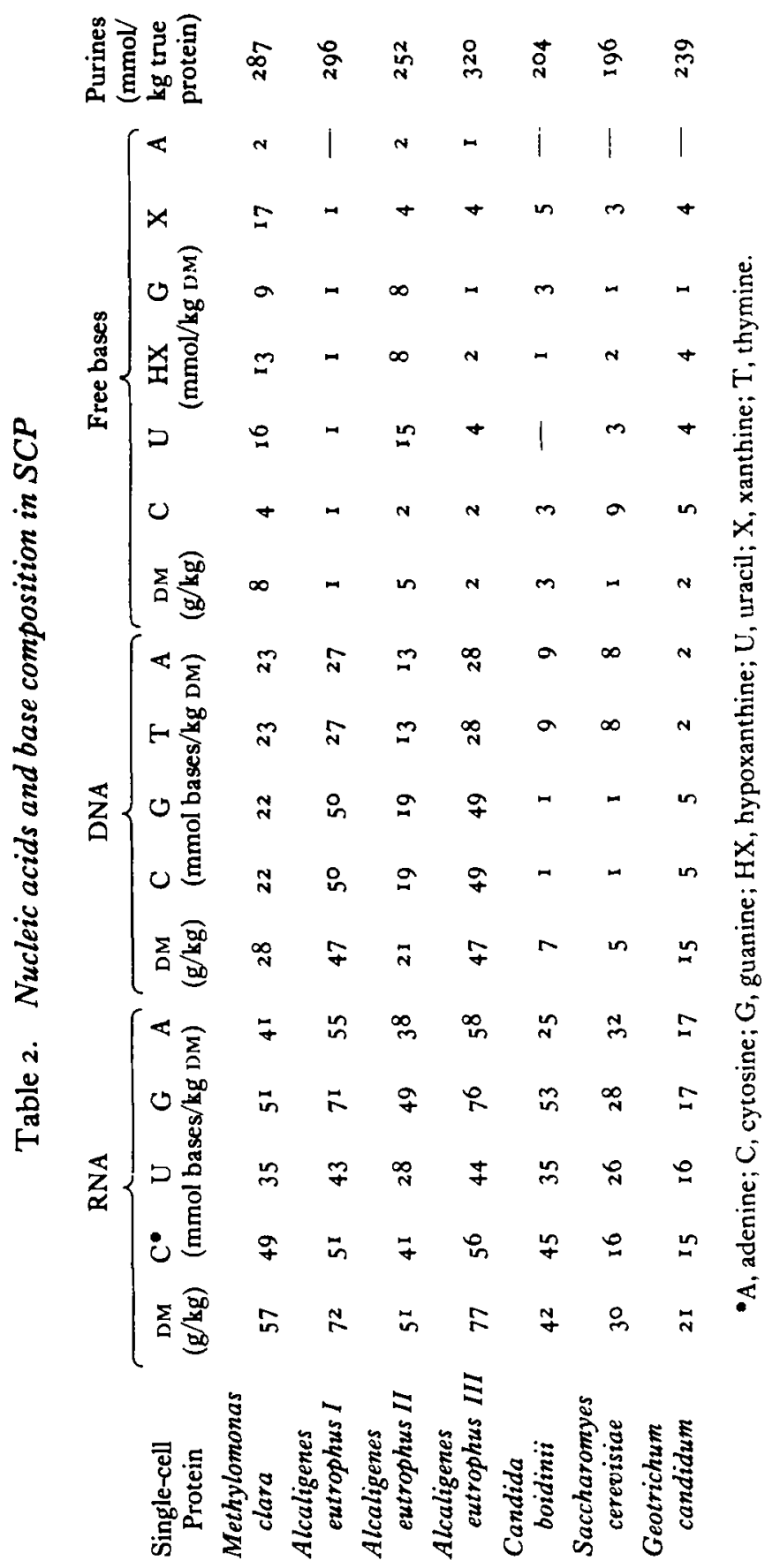


biological function of this enzyme is the recycling of phosphate by decomposing the RNA of microbes produced in the upper digestive tract. Although this hypothesis will not be discussed here, there appears to be a close association between pancreatic RNAase and the microbial activities established in various species. For the cow, rat, pig, chicken, man and dog RNAase concentrations ( $\mu \mathrm{g} / \mathrm{g}$ pancreas) were $1200,260,80,20, I$ and 0.5 respectively. Microbial decomposition of ${ }^{14} \mathrm{C}$-labelled nucleic acids or purines after oral dosage to rats (Greife \& Molnar, r 978,1979 ) and mice (Sonoda \& Tatibana, 1978) has been shown to be responsible for the rapid elimination of ${ }^{14} \mathrm{C}$-metabolites.

It was not surprising that the true digestibility of nucleic acid-N was $9 \mathrm{I}-100$ in rats fed yeast-RNA (Greife \& Molnar, I980) or bacterial SCP of Alcaligenes eutrophus (Greife et al. I981), in piglets fed yeast-RNA (Roth \& Kirchgessner, 1978) and in veal calves fed PRUTEEN (Roth \& Kirchgessner, I979), a bacterial SCP of Methylotrophus methylophilus (ICI, UK). The relatively low level of allantoin excretion in these experiments suggested that the microbial breakdown of purines was remarkable. In the pre-ruminant stage of lambs, however, endogenous factors appear to be responsible for the relatively high renal excretion rate of urate, hypoxanthine and xanthine as compared to allantoin (Razzaque et al. $198 \mathrm{I})$.

Data on the intestinal absorption of purines permitting a comparison of monogastric species on a quantitative basis are not yet available. In mice (Sonoda \& Tatibana, 1978) mainly nucleosides and bases are absorbed, the latter apparently at a faster rate than the former. However, in rats differences in the absorption of individual bases were demonstrated (Savaiano et al. 1980). The carrier-mediated active transport by which hypoxanthine is absorbed in the jejunum of preruminant lambs (Scharrer et al. 1981) has not yet been observed in true monogastric species. In intestinal epithelial cells of rats, which appear unable to synthesize purines de novo, only adenine is used as a precursor (Savaiano \& Clifford, I98I).

It is obvious from the above discussion that monogastric species differ in their physiological characteristics of digestion and metabolism of nucleic acids. Hence the room for generalization of results is very limited. For evaluating SCP products, which for safety reasons cannot yet be tested on volunteers, the dog would appear more suitable than the rat or pig because of the striking similarities of its digestive system to that of man. As the Dalmatian dog has long been known to excrete purines mainly as uric acid (Benedict, I9I6), animals of this breed were proposed as a model for studying nucleic acid availability from SCP (Giesecke et al. 1979). Some comparative results on the Dalmatian dog and man support this view (Table 3).

\section{Metabolic availability of purines from dietary nucleic acids}

If the interference of microbes in the upper digestive tract can be excluded, the renal excretion of extra purines after feeding nucleic acids would reflect that proportion which has been made available to intermediary metabolism by the 
Table 3. Urate metabolism in the Dalmatian dog and man

Sex difference in plasma urate

Pool of plasma urate (mmol)

Increase of plasma urate/g nucleic acids $(\mu \mathrm{mol} / \mathrm{l})$

Increase of plasma urate/g xylitol $(\mu \mathrm{mol} / \mathrm{l})$

Endogenous purine production $(\mathrm{mmol} / \mathrm{d}$ )

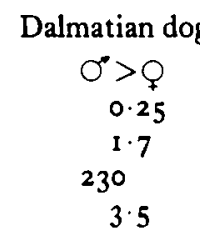

$$
\begin{gathered}
\text { Man } \\
\sigma>Q \\
6.0 \dagger \\
1.9 \dagger \\
2007 \\
2.0 \dagger
\end{gathered}
$$

-From Giesecke \& Maier (1980).

†From Zöllner et al. (1972).

†From Förster \& Hartmann (1977).

intestinal action of nucleolytic enzymes and by absorption. In experiments with adult Dalmatian dogs, a low purine diet $(\mathrm{g} / \mathrm{kg})$ of $25^{\circ}$ casein, approximately 560 carbohydrate and 80 fat was fed as a control and the casein was partly or fully substituted by SCP (Methylomonas clara, Hoechst, West Germany) on a true protein basis. After 2 weeks of adaptation to the diets, 24-h urine collection trials were performed over a period of $\mathrm{I}$ week. Details of the diets and procedures have been reported elsewhere (Gaebler et al. $198 \mathrm{I}$ ), together with results of plasma urate levels. Analyses of dietary purines and urinary metabolites enabled the calculation of the purine input :output relationship shown in Fig. 3.

As indicated by the regression equation the endogenous purine elimination accounted for $3.5 \mathrm{mmol} / \mathrm{d}$. Exogenous purines of SCP increased the daily excretion rate by about $0.6 \mathrm{mmol} / \mathrm{mmol}$ purine intake. The linearity over the wide range of

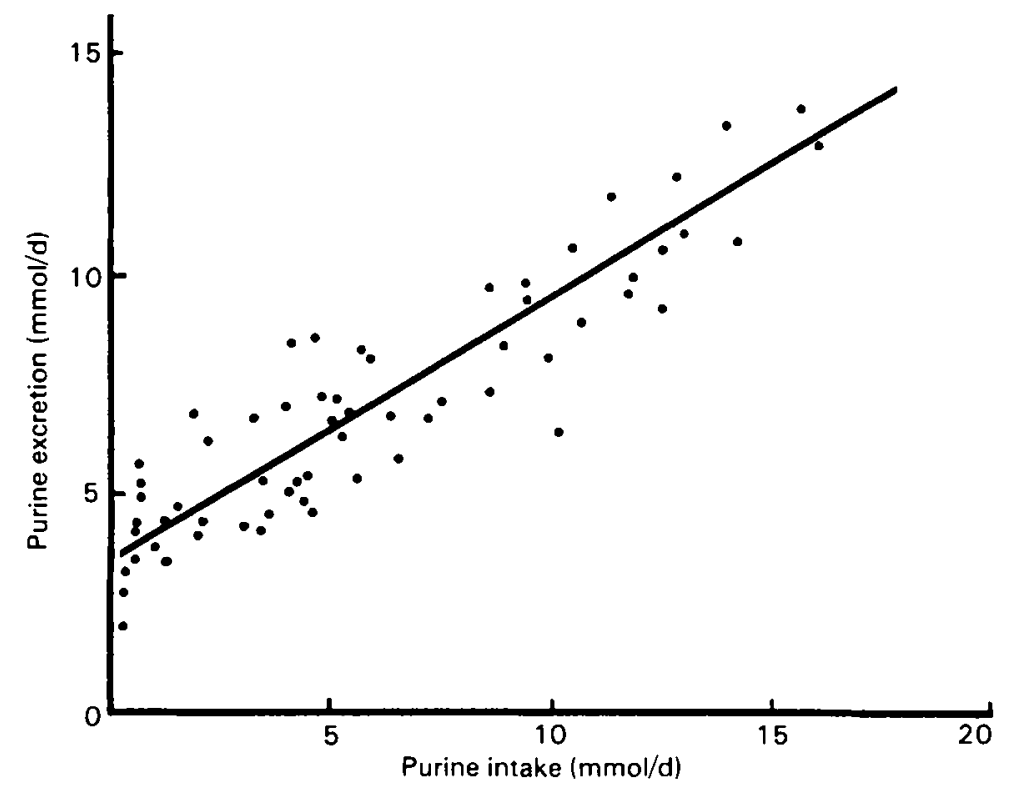

Fig. 3. Relationship between purine intake $(x)$ and renal excretion of purine metabolites $(y)$ in eight Dalmatian dogs given diets containing 97-390 g SCP (Methylomonas clara) $/ \mathrm{kg}$ : $y=0.60 x+3.49 ; n 72, r 0.92, P<0.01$. 
$0.5^{-1} 5 \mathrm{mmol}$ purine intake suggested that exogenous purines induced no apparent feedback inhibition of endogenous purine synthesis. This is in agreement with results obtained with human volunteers who received a purine-free formula diet with defined supplements of RNA or DNA (Gröbner \& Zöllner, 1977). According to the relationship shown above, about $40 \%$ of the nucleic acids consumed were apparently unavailable. Experiments in pre-ruminant lambs fed rumen bacteria with ${ }^{14} \mathrm{C}$-labelled adenine resulted in a value of $58 \%$ for absorption (Razzaque et al. I98I) which is fairly similar to the value of about $60 \%$ obtained in the experiment reported above.

In order to test the availability of SCP nucleic acids in the absence of the protein portion, extracted nucleic acids from the same SCP were added to the control diet in a proportion equivalent to the purine content of SCP. Although the purine intake of dogs on the SCP diet and the casein + nucleic acids diet was virtually identical, the plasma urate levels averaged 160 and $80 \mu \mathrm{mol} / 1$ respectively. Obviously, nucleic acids in SCP and nucleic acids extracted from SCP differed largely in availability. In another experiment the same SCP as before was compared to yeast RNA and the intake and renal excretion of purines measured in six dogs (see Table 4 ). Again a significantly higher availability of dietary purines was shown for the SCP. The somewhat higher content of free bases in this diet as reflected by the amounts of oxypurines ingested could not fully explain this difference. Experiments in man (Clifford et al. 1976) and in rats (Clifford \& Story, 1976; Ho et al. 1979) have shown that individual purines given orally affected the renal excretion of purine metabolites in a different manner, adenine and hypoxanthine being more uricogenic than guanine and xanthine. However, the intake values of these purines differed only slightly between the respective diets as indicated in Table 4. It is possible that free nucleic acids acting as polyanions

\section{Table 4. Influence of yeast $R N A$ and $S C P$ on renal excretion of purine metabolites*}

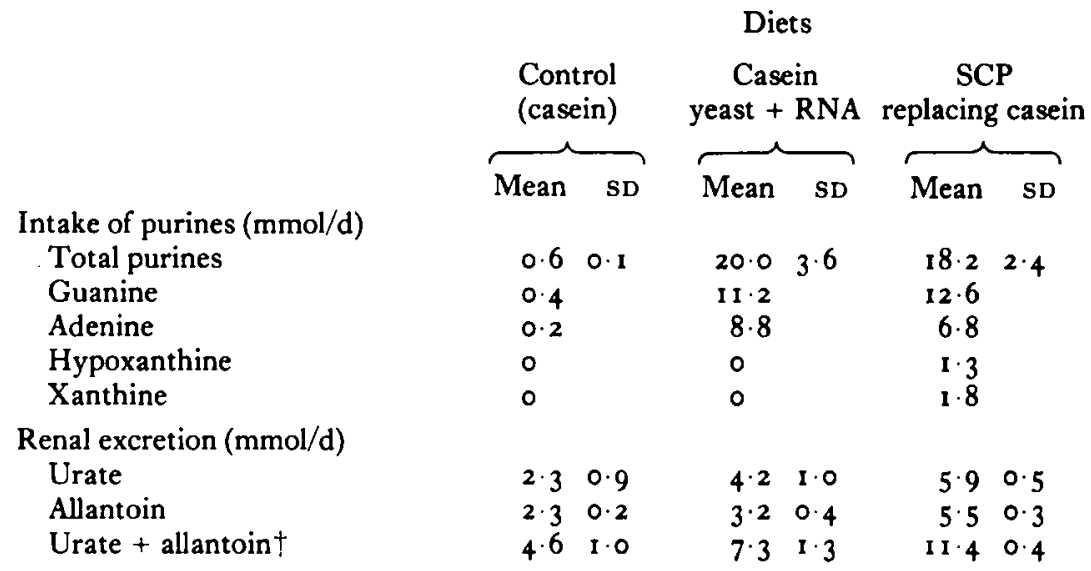

-All values are means ( $t$ SD) of eight $24 \mathrm{~h}$ collection periods in each of six animals.

$\dagger$ Values are significantly different $(P<0.05)$. 
inhibited the pancreatic ribonuclease to a higher extent than the 'slow release RNA' from SCP. This type of inhibition has been demonstrated with DNA in vitro (Sekine et al. 1969).

In this kind of purine-metabolism experiment it is still necessary to establish the proportion of plasma purine metabolites possibly eliminated via the gastrointestinal tract and thus escaping renal excretion. According to the observations of Sørensen (1 960), 25-30\% of plasma urate passed into the gastrointestinal tract in man. In Dalmatian dogs given control or SCP diets the plasma pool of urate was labelled by a continuous infusion of $\left(2-^{14} \mathrm{C}\right)$ urate over $8 \mathrm{~h}$ after feeding. Estimates of its conversion into plasma allantoin and its elimination via urine, the gastrointestinal tract and as respired ${ }^{14} \mathrm{CO}_{2}$ were made. The results are summarized in Table 5. Only at the high urate entry rates of animals on the SCP diet were the small proportions of urate (0.03) and allantoin (0.02) derived from urate eliminated via the gastrointestınal tract. Respired ${ }^{14} \mathrm{CO}_{2}$ accounted for 0.007 of the infused ${ }^{14} \mathrm{C}$-labelled urate. In animals fed the casein diet no measurable flow of urate metabolites into the gastrointestinal tract was found, although the small proportion of ${ }^{14} \mathrm{CO}_{2}$ respired may indicate some elimination of urate metabolites via the gastrointestinal tract.

\section{Conclusions}

The recent progress in the analysis of nucleic acids in dietary constituents will help to improve the interpretation of nitrogen balance trials. It also permits a proper definition of the kinds and linkages of purines in SCP and other protein sources, thus providing a reasonable estimate of the dietary purine load. Obviously, the metabolic availability of nucleic acids and of purines in particular cannot yet be predicted simply on the basis of analytical data. The proposed animal model with dogs provides a method for evaluating the metabolic availability of nucleic acids.

Table 5. Effect of SCP feeding on entry and elimination rates of plasma urate and allantoin*

\begin{tabular}{|c|c|c|}
\hline & $\begin{array}{l}\text { Control diet } \\
\text { (casein) }\end{array}$ & $\begin{array}{c}\mathrm{SCP} \\
\text { replacing casein }\end{array}$ \\
\hline Entry rate of plasma urate ( $\mathrm{nmol} / \mathrm{kg}$ per $\mathrm{min}$ ) & 189 & 693 \\
\hline \multicolumn{3}{|l|}{ Proportion of entry rate } \\
\hline Conversion into allantoin & 0.19 & $0 \cdot 37$ \\
\hline Renal urate & 0.85 & 060 \\
\hline Renal allantoin & 0.19 & 0.35 \\
\hline Intestinal urate & $N D+$ & $\circ 03$ \\
\hline Intestinal allantoin & ND & 0.02 \\
\hline Respiratory $\mathrm{CO}_{2}$ & 00001 & 0007 \\
\hline
\end{tabular}

- Measured by continuous infusion of $\left(2-{ }^{14} \mathrm{C}\right)$ urate for $8 \mathrm{~h}$ in two dogs for each diet (Stangassinger, Gaebler \& Giesecke, unpublished).

${ }^{+} \mathrm{N} I$ ), not detected. 
Even with high SCP diets only up to $5 \%$ of the plasma purine entry rate will escape renal excretion.

The Dalmatian dog, as an animal model for man, has been shown to be helpful to our better understanding of nucleic acid digestion and should eventually allow the prediction of the metabolic effects of dietary purines and pyrimidines in animals and man exclusively on the basis of chemical analysis.

\section{REFERENCES}

Anon. (1976). Documents on Single Cell Protein issued by PAG, p. 26. New York: ProteinCaloric Advisory Group, United Nations.

Barnard, E. A. (1969). Nature, Lond. $221,34^{\circ}$.

Benedict, S. R. (1916). Harvey Lect. 11, 364 .

Clifford, A. J., Riumallo, J. A., Young, V. R. \& Scrimshaw, N. S. (1976). F. Nutr. 106, 428.

Clifford, A. J. \& Story, D. L. (1976). F. Nutr. 106, 435.

Förster, H. \& Hartmann, H. (1977). Infusionstherapie 4, 158.

Gaebler, S., Maier, J., Tiemeyer, W. \& Giesecke, D. (1981). Zbl. Vet. Med. A28, 494.

Giesecke, D. \& Maier, J. (1980). Ernährungsumschau 27, $28 \mathrm{r}$.

Giesecke, D., Tiemeyer, W. \& Maier, J. (1979). Vär Föda, Suppl. 3, I76.

Greife, H. \& Molnar, S. (1978). Z. Tierphysiol., Tierernährg. u. Futtermittelkde. 40, 248.

Greife, H. \& Molnar, S. (1979). Z. Tierphysiol., Tierernährg. u. Futtermittelkde. 41, 184.

Greife, H. \& Molnar, S. (1980). Z. Tierphysiol., Tierernährg. u. Futtermittelkde. 43, 213.

Greife, H., Molnar, S. \& Günther, K.-D. (1981). Z. Tierphysiol., Tierernährg. u. Futtermittelkde. 45, 91 .

Gröbner, W. \& Zöllner, N. (1977). Nutr. Metab. 2 I, 6.

Hartwick, R. A. \& Brown, P. R. (1976). F. Chromatogr. 122, 679.

Ho, C. Y., Miller, K. V., Savaiano, D. A., Crane, R. T., Ericson, K. A. \& Clifford, A. J. (Iģ79). F. Nutr. I09, 1377 .

Kharatyan, S. (1978). Ann. Rev. Microbiol. 32, 30r.

Razzaque, M. A., Topps, J. H., Kay, R. N. B. \& Brockway, J. M. (1981). Br. F. Nutr. 45, 517.

Roth, F. X. \& Kirchgessner, M. (1978). Z. Tierphysiol., Tierernährg. u. Futtermittelkde. 40, 315.

Roth, F. X. \& Kirchgessner, M. (1979). Arch. Tierernähr. 29, 275.

Savaiano, D. A. \& Clifford, A. J. (1981). F. Nutr. 111, 1816.

Savaiano, D. A., Ho, C. Y., Chu, V. \& Clifford, A. J. (1980). F. Nutr. $110,1793$.

Scharrer, E., Raab, W., Tiemeyer, W. \& Amann, B. (198I). Pflügers Arch. 391, 4 I.

Scrimshaw, N. S. \& Dillon, J.-C. (1979). In Single-Cell Protein-Safety for Animal and Human Feeding, p. 17 I [S. Garattini, S. Paglialunga \& N. S. Scrimshaw, editors]. Oxford: Pergamon Press.

Sekine, H., Nakano, E. \& Sakaguchi, K. (1969). Biochim. Biophys. Acta 174, 202.

Sonoda, T. \& Tatibana, M. (1978). Biochim. Biophys. Acta 52 1, 55.

Sørensen, L. B. (1 960). Scand. Y. Clin. Lab. Invest. 12, Suppl. 54.

Tiemeyer, W., Erbersdobler, H. \& Giesecke, D. (1981). Z. Lebensm. Unters. Forsch. 173, 301.

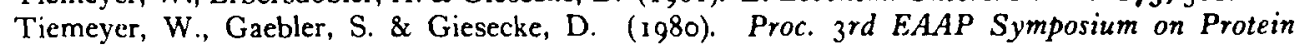
Metabolism and Nutrition, vol. I, p. 137 [H. J. Oslage and K. Rohr, editors]. EAAP-Publ. No. 27.

Tiemeyer, W., Gaebler, S. \& Giesecke, D. (1982). Landw. Forsch. (In the Press.)

Tiemeyer, W. \& Giesecke, D. (1982). Analyt. Biochem. (In the Press.)

Tiemeyer, W., Stohrer, M. \& Giesecke, D. (1982). Ernähr.-Umschau (In the Press.)

Zöllner, N., Griebsch, A. \& Gröbner, W. (1972). Ernähr.-Umschau I9, 79. 